\title{
Self-Introspection in Teaching Students with Virtual Learning in COVID-19 Pandemic:
}

\author{
A Qualitative Finding
}

\author{
Bagus Hary Prakoso* \\ Center for Assessment and Learning \\ Ministry of Education and Culture \\ Jakarta, Indonesia \\ *bagus.hary@kemdikbud.go.id
}

\author{
Zulmi Ramdani, Bilqisthi Rahmah \\ Faculty of Psychology \\ UIN Sunan Gunung Djati Bandung \\ Bandung, Indonesia \\ zulmiramdani@uinsgd.ac.id, bilqisthirahmah08@gmail.com
}

\begin{abstract}
Pandemic COVID-19 has changed the learning process to become virtual. One consequence of these changes is related to online learning methods and schemes which in fact experience various technical and substantive constraints. The case study research design was carried out to strengthen the hypothesis that self-introspection is able to make learning more optimal. Learning outcomes before and after self-introspection are measured using thematic content analysis. The results show that there are changes in emotional feelings to be more positive, reduced task load, and reduced stress levels with methods and learning schemes that follow the principle of self-introspection. Thus, this study explains that if every teacher is able to realize the location of deficiencies and errors in the teaching process, it will minimize the occurrence of psychological disorders for students and be able to improve learning outcomes for the better.
\end{abstract}

Keywords-COVID-19, learning performance, selfintrospection, teaching process, virtual learning

\section{INTRODUCTION}

The COVID-19 pandemic has had a significant effect on the existing learning process. This influence can be seen from the change in learning systems to be online-based or online. Online learning is a learning method that is carried out virtually, which is not face-to-face but using internet-based media that can facilitate teachers and students to interact directly [1].

Online learning certainly provides a variety of benefits and convenience for teachers and students to get certain lessons. The use of online-based media will make it easier and faster to provide information that may not be reachable directly [2]. In addition, online media can be an alternative media to provide entertainment for students, especially because it can integrate it with technological developments and the times [3]. Other benefits that can be generated from virtual learning include providing fun media for learning [4], provide more motivation to use creative media [5], as well as being another reference material to create more interesting learning [6].
In fact, online learning during a pandemic often creates many new problems. These problems can be in the form of technical constraints found related to limited unequal accessibility and difficulties in accessing the network. Even crucial problems that result in disruption of the emotional stability and health of student. These things may result in online learning not being optimal [7-9]. One of the factors that occur is due to the ineffective learning mechanisms and methods of lecturers or teachers.

Facts in the field show that many students complain that the burden of assignments given online is increasing. What's more, many of them are stressed not only by their college assignments but also with the pressure at their home. Short interviews conducted by researchers also showed the results that most of the students felt tremendous stress with the demands of online lectures. This is also supported by the media and boring learning methods so that it becomes a detrimental factor for the students themselves. To achieve a more stable condition and be able to anticipate the phenomenon that occurs, many lecturers or other teachers try to self-reflect on what they are doing during the online learning process. The purpose of this research itself is to see in depth the description of the respondent's situation when online learning is carried out by focusing on changes in the learning system due to selfreflection activities. The research framework can be seen in Figure 1.

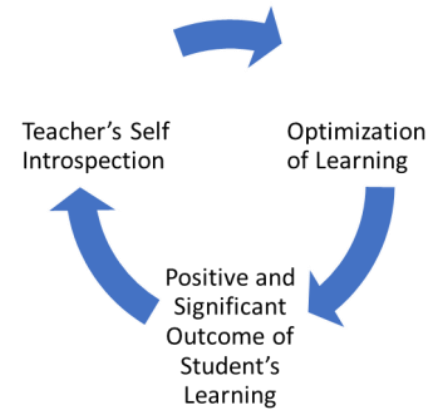

Fig. 1. Research framework 


\section{LITERATURE REVIEW}

\section{A. Self Introspection in Psychology}

Introspection in psychology results in a change in attitude, in line with the motives found in the individual. Introspection in itself changes the way individuals see and predict their future [10]. Traditionally, introspection refers to the active process by which a person becomes aware of their inner state. Introspection refers to content that results from deliberate acts of self-monitoring as well as effort and evaluation of ongoing conscious experiences, such as when one directs one's conscious mind to another conscious state [11]. Cognitive insight is an important part of the self-introspection process including evaluation and reinterpretation of beliefs and assessments of something. Cognitive insights will be associated with a variety of neuropsychological functions, but will be closely related to measures of executive function [12]

\section{B. Related Variables to Self-Introspection}

Self-introspection is an important part that must be owned by someone to see the symptoms that exist in them and try to provide improvements to things that are considered wrong. This self-introspection is directly related to a person's ability to understand what is his strengths and weaknesses which will then increase other factors such as optimism and self-efficacy that he has [13]. In addition, self-introspection is also related to how a person evaluates themselves in depth. This can improve the welfare that occurs in these individuals [14] and also do better self-management [15].

\section{METHODS}

This research uses a qualitative approach. This approach is carried out to explore the phenomena raised in research Ramdani [16]. The topic studied by the researcher was selfintrospection in the learning process.

\section{A. Sample}

Respondents in this study were 30 students who were selected by purposive sampling technique. The characteristics that are determined are students who are following the online learning process.

\section{B. Instruments}

The study used an open questionnaire instrument consisting of several questions covering what respondents felt during online learning and things that must be considered by the lecturer to improve the learning system so that it was more optimal. The questions used follow the guidelines derived from the studies conducted by Rădulescu and Iucu [17]. In the implementation, the lecturer or teacher will evaluate the things that are felt to be lacking in learning that come from the student's own input then change the learning system according to the good points that can be optimized from what is done.

\section{Collecting and Analysing Data}

Data was collected by distributing open questionnaires related to online questions, then filled in by respondents according to the characteristics of the study. Data analysis was carried out by using thematic content analysis to identify holistically the information that emerged from the respondent's answer then categorize and interpret what was obtained [18]. To get the objectification of what is interpreted, the researcher uses multi-judgment by asking people who are considered experts in topics outside the researcher himself.

\section{RESULTS AND DisCUSSIONS}

This study uses an open questionnaire. In this open questionnaire, the researcher presents an overview of the problems experienced by students during their online lectures, before the lecturer introspects how to teach in the midst of the Covid-19 pandemic and the conditions experienced by students after the lecturer introspects.

Based on the questionnaire, the researcher obtained the results that the problems experienced by students before the lecturer did introspection were related to (1) lecture time management; (2) the teaching system of the lecturers, (3) the use of lecture media; (4) network constraints and narrow task deadlines, and (5) physical complaints during online lectures.

In terms of time management, students feel that meetings often exceed the appropriate class hours. The long lecture time and there is no break for rest are a burden for students. The following is a sample that shows this problem.

"The definite time management can be maximized again. Because some meetings exceed the time they should. It is indeed difficult because of this pandemic constraint"

\section{"The lecture time did not match the schedule"}

"I think the lecture a while ago, was tough because of the short break time"

Furthermore, in terms of the teaching system, students felt that the lecturer's teaching method that was considered too tense caused them to feel depressed. In addition, the delivery of material that is too dense along with explanations that are too fast and uses complicated language makes it difficult for students to understand the material. The following is a sample that shows this problem.

"Maybe the way, tense every meeting. So understand, but a little depressed"

"If I personally find it difficult to understand what is being conveyed because the language is not easy to understand, maybe it can be corrected for the way of delivering the material so that it uses language that is easy to understand"

"The material discussion system is more detailed and is applied to real examples (applications), for the rest it can be understood" 
In addition, the use of inappropriate media can cause confusion in students in understanding the material and cause student limitations in doing assignments. The following is a sample that shows this problem.

"Giving assignments using google doc, this is often a lot of obstacles because many people have access to it"

"The use of google doc likes errors, the collection of tasks prefers to use WhatsApp or Gmail"

"In my opinion, using google doc always has problems, because there are so many people who access and edit their documents, so they are often lagging until they are late collecting"

The next problem most students experience is internet network constraints. This makes them sometimes late in collecting any tasks that are given a narrow time frame or deadline. The following is a sample that shows this problem.

"The network is not always stable so sometimes it is not possible to collect tasks at the limited time, not because it was just finished but because of the network"

"Because during online lectures like this the biggest obstacle is the signal and internet network, so if for example given an additional time limit to collect I think it's enough"

"In terms of deadline for assignments, because sometimes the internet network likes errors, less time causes late submission of assignments"

Finally, busy class schedules and requiring students to do virtual learning during this pandemic have caused students to complain of physical pain such as headaches. The following is a sample that shows this problem.

"I think the lecture some time ago, felt heavy because of the short break time, I often had migraines and fever"

However, after the lecturer evaluated or introspected the way he taught in the midst of the Covid-19 pandemic and changed the way he taught as expected by students, there was also a more positive change in students. These changes are related to the learning atmosphere which is considered more enjoyable, the teaching system which is considered effective and structured so that students understand the material more easily, and there are no physical complaints that are felt.

After the lecturer changed the way he taught differently from before, students considered the learning atmosphere more relaxed and enjoyable. This is also because the media used in teaching are more varied, such as using virtual meetings via google meet or zoom accompanied by material explanations via voice notes and discussions via WhatsApp. Here is a sample that shows this.

"Lecturing via google meeting or zooming is one of the most effective ways to be followed by lectures via WhatsApp"
"Maybe more often, the explanation is through the virtual meeting pack (G-meet) because it's a very effective method"

"Overall you are great, creating methods by conveying voice note and clear exposure via zoom or google meet"

In addition, the teaching system is also considered effective and structured. Students can slowly understand the material given because it is explained clearly and in detail and the language used is simpler than before and there are repetitive explanations of material that are considered difficult. Here is a sample that shows this.

"The learning strategy has been very good during this pandemic, in the future maintain this very interesting consistency of learning which makes contour courses easier to understand"

"In my opinion, the learning process of this material is good and structured"

"Because it is online now, so in my opinion it is very good compared to other course systems"

Furthermore, based on the results obtained in an open questionnaire about the changes experienced by students after the lecturer changed their teaching methods, there were no physical complaints experienced by students. In this case, the learning atmosphere and learning strategies that are made attractive make students enjoy the lectures that are conducted online.

The study results convey a comprehensive picture of the phenomena that occur in the field related to what respondents feel during the online learning process. The problems described earlier are problems commonly found in teaching and learning activities, especially those felt by students in getting learning. As a student, of course the problems found are related to the many assignments and requirements of the lecture, the economic factors that are obtained, the interaction with the family and social environment, and also other problems that occur every day [19]. These results are the same as what students felt when the early days of online learning were carried out. The most severe problems experienced were related to the stress of heavy tasks and increased by ineffective learning systems.

After the self-introspection activity was carried out, there was a significant change in the learning process where the lecturer no longer gave a lot of workloads and only tried to ensure that the material was well received. In addition, learning also pays close attention to the psychological condition of students by always asking and discussing the best and most effective activities during a pandemic. Lecturers also always discuss other matters that personally help students to overcome the problems they face. These methods are considered in accordance with the conditions experienced by students during the pandemic.

Self-introspection activities that are true will involve deep seriousness of each individual who does it. This is in accordance with several studies that explain the virtue of self- 
introspection. Self-introspection is considered as a model of self-evaluation that is useful for someone to get new behaviors which are directly and indirectly able to develop appropriate traits and behaviors $[11,12,20]$.

\section{CONCLUSION}

This study explains that teacher need to conduct thorough introspection in the aspects of learning so that they can see clearly what students feel and correct that go wrong for the better.

\section{ACKNOWLEDGMENT}

This study is the result of a routine collaboration initiated by the Center for Assessment and Learning, the Ministry of Education and Culture of the Republic of Indonesia and the Psychology Faculty of UIN Sunan Gunung Djati Bandung. We would like to thank all the respondents who were involved in this research activity.

\section{REFERENCES}

[1] S. Philippe, A.D. Souchet, P. Lameras, and P. Petridis, "Multimodal teaching, learning and training in virtual reality: a review and case study,"Vr-Ih.Com, vol. 2, no. 5, pp. 421-442, 2020.

[2] Z. Ramdani, T. Widyastuti, and F.R. Ferdian, "Penerapan analisis teori klasik, model Rasch, dan computer based test Moodle: Sebuah pilot studi," 2018. doi: 10.26499/ijea.v1i2.9.

[3] M. Sholihin, R. Candra, N. Yuniarti, and S. Ilyana, "A new way of teaching business ethics: The evaluation of virtual reality-based learning media,” Int. J. Manag. Educ., vol. 18, no. 3, p. 100428, 2020.

[4] H.R. Dharma, D. Asmarani, and U.P. Dewi, "Basic Japanese Grammar and Conversation e-learning through Skype and Zoom Online Application," Procedia Comput. Sci., vol. 116, pp. 267-273, 2017.

[5] F.G. Escobar Fandiño and A.J. Silva Velandia, "How an online tutor motivates E-learning English,” Heliyon, vol. 6, no. 8, 2020.

[6] P.T. Lautala, P.J. Haas, and J.L. Velat, "High Speed Rail Learning System (HSRLS) - Taking Advantage of Online Technologies in Railway Education,” Int. J. Transp. Sci. Technol., vol. 4, no. 2, pp. 179196, 2015.

[7] R. Marliani, E. Nasrudin, R. Rahmawati, and Z. Ramdani, "Regulasi Emosi, stres, dan kesejahteraan Psikologis : Studi pada ibu work from home dalam menghadapi pandemi COVID-19," 2020. [Online]. Available: http://digilib.uinsgd.ac.id/30722/.

[8] P. Odriozola-González, Á. Planchuelo-Gómez, M.J. Irurtia, and R. de Luis-García, "Psychological effects of the COVID-19 outbreak and lockdown among students and workers of a Spanish university,' Psychiatry Res., vol. 290, no. May, p. 113108, 2020.

[9] W. Cao, "The psychological impact of the COVID-19 epidemic on college students in China," Psychiatry Res., vol. 287, no. March, p. 112934,2020 .

[10] L. Ivan, "Introspection on Romantic Relation Generates Attitudinal Change," Procedia - Soc. Behav. Sci., vol. 78, pp. 370-374, 2013.

[11] R. Brown, H. Lau, and J.E. LeDoux, "Understanding the Higher-Order Approach to Consciousness," Trends Cogn. Sci., vol. 23, no. 9, pp. 754 768, 2019.

[12] M.A. Cooke, E.R. Peters, D. Fannon, I. Aasen, E. Kuipers, and V. Kumari, "Cognitive insight in psychosis: The relationship between selfcertainty and self-reflection dimensions and neuropsychological measures," Psychiatry Res., vol. 178, no. 2, pp. 284-289, 2010.

[13] R. Falanga, M.E. De Caroli, and E. Sagone, "Self-efficacy Beliefs and Representation of Self and Psychology A Longitudinal Study with Psychology University Students," Procedia - Soc. Behav. Sci., vol. 140, pp. 295-299, 2014.

[14] Y. Shi, "Effects of a nurse-led positive psychology intervention on sexual function, depression and subjective well-being in postoperative patients with early-stage cervical cancer: A randomized controlled trial," Int. J. Nurs. Stud., vol. 111, no. 74, p. 103768, 2020

[15] F. Görges, C. Oehler, E. von Hirschhausen, U. Hegerl, and C. Rummel Kluge, "GET.HAPPY - Acceptance of an internet-based selfmanagement positive psychology intervention for adult primary care patients with mild and moderate depression or dysthymia: A pilot study," Internet Interv., vol. 12, no. March, pp. 26-35, 2018.

[16] Z. Ramdani, "Forgiving is not only forgetting (phenomenological study on forgiveness in individual who experiences a friendship conflict)," IJASOS-International E-Journal Adv. Soc. Sci., vol. III, no. 9, pp. 829839, 2017.

[17] C. Rădulescu and R. Iucu, "The Importance of Developing a Sense of Self as a Teacher During the Training Programmes," Procedia - Soc. Behav. Sci., vol. 127, pp. 401-405, 2014.

[18] L.F. Tae, Z. Ramdani, and G.A. Shidiq, "Analisis tematik faktor-faktor yang mempengaruhi keberhasilan siswa dalam pembelajaran sains," Indones. J. Educ. Assess., vol. 2, no. 1, pp. 79-102, 2019.

[19] Z. Ramdani, T. Supriyatin, and S. Susanti, "Perumusan dan pengujian instrumen alat ukur kesabaran sebagai bentuk coping strategy," J. Psikol. Islam dan Budaya, vol. 1, no. 2, pp. 97-106, 2018.

[20] H. Xue and P.M.A. Desmet, "Researcher introspection for experiencedriven design research,” Des. Stud., vol. 63, pp. 37-64, 2019 